\title{
Assessment of the Coastal Sensitivity Using the CS Index in the Gulf of Gabes Tunisia; Southern Mediterranean Coast
}

Maher Gzam ( $\sim$ maher.gzam@univgb.tn )

University of Gabes: Higher institute of water sciences and technics of Gabes https://orcid.org/00000002-5222-9144

\section{Basma Mansouri}

University of Gabes: Universite de Gabes

\section{Dorra Gargouri}

Faculty of Sciences of Sfax: Universite de Sfax Faculte des Sciences de Sfax

\section{Adel Kharroubi}

university of Gabes; Higher Institute of Water Sciences and Technics

\section{Research Article}

Keywords: sensitivity, CSI, variables, planning, degradation, Gulf ofGabes

Posted Date: December 13th, 2021

DOI: https://doi.org/10.21203/rs.3.rs-1098137/v1

License: (c) (i) This work is licensed under a Creative Commons Attribution 4.0 International License. Read Full License 


\section{Abstract}

Assessment of the coastal degradation using the coastal sensitivity index (CSI) in the microtidal environment (Gulf of Gabes, Tunisia) shows that $78.6 \%$ of the coast is under low to moderate sensitivity. Moderate sensitivity class includes the sheltered zones and the stable sea cliffs. The highest sensitivity was recorded in sandy beaches $(12.7 \%)$ where the drift actions amplify littoral fragility and flood risk. The coastal sensitivity index (CSI) is resulted from the combination of eight ranked variables: (a)

geomorphology (b) coastal slope (c) hinterland topography (d) facies (e) shoreline exposure (f) shoreline changes (g) tide $(\mathrm{h})$ sea-level trend. Fifty six morphodynamic cells are deduced from a strictmorphologic classification of the studied coast. Each specified cell presents a numerical pattern according to the ranked physical and structural variables. Once managed, the beaches with the highest sensitivity are immediately disturbed. Littoral disturbance is irreversible when the foredune unit is damaged but sustainable remediation of coastal areas must emphasize with the adequate planning for the environmental rehabilitation.

\section{Introduction}

Since the beginning of the 20th century the Tunisian coast has undergone profound morphologic changes due to the man induced activities (Oueslati, 2004; Kharroubi et al., 2012; Gzam, 2013; Brahim et al., 2014; 2015). Coastal urbanization induces the dysfunction of the coastal area (Gargouri et al., 2018). This pressure interferes to the increased frequency of storm eventsthat amplify the risks of erosion and wetlands inundation (Saïdi et al., 2011). Beachesin the Gulf of Gabes are largely disturbed by tourism activities. Each year, several meters of the coasts disappeared due to the storm events (Bouchahma and Yan, 2014). The considerable losses of dunes and beaches around urbanized areas compromise safety against flooding (Bouchahma and Yan, 2014). Additional complications of littoral disturbance are amplified by the construction of harbor infrastructures which are threatened by the silting up problem (Paskoff, 1994; Magherbi, 1995; Ben Amor et al., 2003; Bejaoui et al., 2004; Bardi, 2010; Gzam et al., 2013a; Gzam et al., 2014). Therein it's necessary to evaluate the coastal sensitivity using the index approach in order to recommend the adequate criteria's for use in littoral planning. Thus, mapping the relative sensitivity of coastal area allows the identification of potential sites susceptible to integrate human activities. The adopted approach in this study includes only the physical variables for assessing littoral sensitivity. Several methods are used to assess littoral sensitivity based on the combination of numerical ranked parameters (Gornitz, 1990; Gibb et al., 1992; Shaw et al., 1998; Diez et al., 2007; Abuodha and Woodroffe, 2010; Palmer et al., 2011; Koroglu et al., 2019). In this study the coastal index sensitivity was evaluated by thestraight-forward additive approach of the ranked parameter. This approach can be rapidly calculated and does not distort the data (Gibb et al., 1981).

\section{Study area}

The study area belong the central part of the Gulf of Gabes which includes the coastal lagoon of Boughrara and Jerba Island (Figure 1; Sammari et al., 2006; Gzam et al., 2013b; 2014). The development 
of coastal area in a sustainable way presents a challenging task. The littoral planning and management occurs without recommendation of preventive solutions. The fixed shorelines are threatened by erosion and human activities. The microtidal sandy beaches of the Gulf of Gabes are altered distorted due to the excessive occupation of the harbor infrastructures (e.g. Aghir and Gabes harbors, Figure 2). By 1882, the harbor of Gabes city was built around a former tidal inlet. Between 1896 and 1992, several extension works were undertaken on the port to increasethe basin capacity (Sogreah, 2003). Actually, the construction corresponds on two dikes: the northern dike which ends with a pierhead that ensures a relative stability of the sea water. The southern dike remains perpendicular to the coast. The fishing harbor of Aghir coast is constructed by 1997 at the southern-east of Jerba Island. It consists to a long jetty ( $250 \mathrm{~m}$ of length) where it forms a safe anchorage for ships. It's equipped by a large pass $(70 \mathrm{~m})$ for discharging the southward sediments transit (toward the sand spit of Kastil). By 2013, severe sediment accumulations are observed in the basin and around the quay. This pressure is amplified by the growing treat of littoral occupation. More than $70 \%$ of the island's population lives on thecoastwhere average altitude is about $7 \mathrm{~m}$. The hotel expansion was done by aspectacular hotel boom since 1990 (Bouchahma and Yan, 2014). The deterioration of water quality in Boughrara Lagoon is due to the continued discharge of waste and contaminant liquids leading to the eutrophication and a netreduction of the fishing resources (Kharroubi et al., 2012).

\section{Methods}

Subdividing the coast to a coherent morphologic transects is a key step to perform thelittoral sensitivity map. The delimitation criteria's are based on the coherence of the morphodynamic cells that includes littoral features, substrate slope and hydrodynamic forcing. Thus the studied coast (about $358 \mathrm{~km}$ ) is subdivided to fifty six morphodynamic cells in which the stretch of coast is digitized and converted to numerical data base. A user guideline of geomorphologic typology (Gibb et al., 1981) is adopted for the data and their representation in terms of sensitivity and risk. The Coastal Sensitivity Index CSI formula (Gibb et al., 1981; Gornitz, 1990; Ramieri et al., 2011; Palmer et al., 2011) consists to the combination of a number of semi-quantifiable variables, comprising four structural variables (a) geomorphology; (b) hinterland topography; (c) coastal slope; (d) sediment facies and four process variablessuch the (e) shoreline exposure $(\mathrm{f})$ shoreline changes $(\mathrm{g})$ tide and $(\mathrm{h})$ sea-level trend. A large database was constructed and the Table 1 describes the variables used to compute the CS index. Each of the variables was weighted according to its end effects on the coastal area. A score ranging from 1-5 in order of increasing sensitivity of each variable; 1 being the lowest contribution to coastal sensitivity, 5 being the highest (Tab. 1). The non-numerical variables (geomorphology, hinterland topography, coastal slope, facies, and hydrodynamic processes), are ranked according to the relative resistance of the coast. From each costal transect a single numerical value was calculated by the CSI formula. Once ranking is complete the sum of ranked variables is used to calculate a single numerical value that defines the sensitivity of each section. Cliffed coasts, sheltered rocky coasts and the associated hinterland topography are ranked as lower risk. Hydrodynamic processes rank the fully exposure of coastal sections to inundation as high risk. Numerical variables are assigned a risk ranking based on data value ranges. 
The CSI formula was calibrated and compared with field in order to evaluate the littoral evolution upon different scenarios of planning. Two sites (Gabes and Aghir harbors) threatened by silting problem were analyzed and calibrated with the established sensitivity map. GIS-data's analysis through aerial photographs $(1963,1999)$ and Google Earth images $(2003,2008,2010$ and 2016$)$ were used to extract the origin and the causes of harbor silting up.

Table 1

Ranking of coastal vulnerability index variables

\begin{tabular}{|c|c|c|c|c|c|}
\hline & Very low & Low & Moderate & High & Very high \\
\hline Variable & 1 & 2 & 3 & 4 & 5 \\
\hline Geomorphology & Cliffs & $\begin{array}{l}\text { Rocky } \\
\text { coasts }\end{array}$ & Beaches & $\begin{array}{l}\text { Spit and barrier } \\
\text { island }\end{array}$ & $\begin{array}{l}\text { Flat and } \\
\text { marsh }\end{array}$ \\
\hline $\begin{array}{l}\text { Hinterland } \\
\text { topography }\end{array}$ & High plateau & $\begin{array}{l}\text { Former } \\
\text { outcrops }\end{array}$ & Smooth shape & Sebkha & Lagoon \\
\hline Coastal slope & $0.03-0.059$ & $0.06-0.1$ & $0.11-0.3$ & $0.31-0.5$ & $0.51-0.77$ \\
\hline $\begin{array}{l}\text { Sediment } \\
\text { facies }\end{array}$ & $3.5-3.2$ & $3.1-2.8$ & $2.7-2.4$ & $2.3-2$ & $1.9-1.6$ \\
\hline \multicolumn{6}{|l|}{ 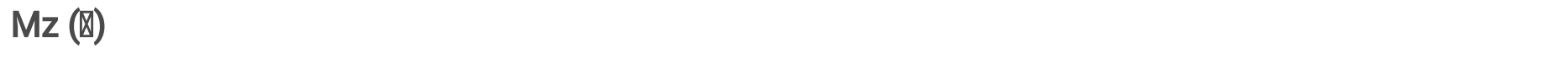 } \\
\hline $\begin{array}{l}\text { Shoreline } \\
\text { exposure }\end{array}$ & $\begin{array}{l}\text { Very } \\
\text { sheltered }\end{array}$ & Sheltered & Semi-exposed & Exposed & $\begin{array}{l}\text { Fully } \\
\text { exposed }\end{array}$ \\
\hline $\begin{array}{l}\text { Shoreline } \\
\text { changes }\end{array}$ & Progradation & Stable & $\begin{array}{l}\text { Tendency } \\
\text { towards stability }\end{array}$ & $\begin{array}{l}\text { Tendency } \\
\text { towards erosion }\end{array}$ & Erosion \\
\hline Tide & 2 & $1.9-1.5$ & $1.4-1.1$ & $1-0.7$ & $\leq 0.6$ \\
\hline Sea-level & $1-1.6$ & $1.7-2.2$ & $2.3-2.8$ & $2.9-3.4$ & $\geq 3.5$ \\
\hline \multicolumn{6}{|c|}{$\begin{array}{l}\text { (a) geomorphology (b) coastal slope }(\mathrm{c}) \text { hinterland topography }(\mathrm{d}) \text { facies }(\mathrm{e}) \text { shoreline exposure }(\mathrm{f}) \\
\text { shoreline changes }(\mathrm{g}) \text { tide }(\mathrm{h}) \text { sea-level trend. }\end{array}$} \\
\hline \multicolumn{6}{|c|}{$C V I=\mathrm{a}+\mathrm{b}+\mathrm{c}+\mathrm{d}+\mathrm{e}+\mathrm{f}+\mathrm{g}+\mathrm{h}$} \\
\hline \multicolumn{6}{|c|}{ (Gibb, 1981, 1992; Palmer et al. 2011) } \\
\hline
\end{tabular}

\section{Results}

\section{Coastal sensitivity index}

The coastal sensitivity describe here the integrate information from eight parameters. The theoretical value of each of the selected variables is included in the matrix based on user guidelines. The structural variables are (a) geomorphology; (b) hinterland topography; (c) coastal slope; (d) sediment facies. The physical variables are (e) shoreline exposure (f) shoreline changes (g) tide (h) sea-level trend. 


\section{Geomorphology}

Coastal morphology is the interplay between hydrodynamic processes and landforms. Beaches and sandy spits of Jerba Island are sensitive to the changes in energy and human influences. The common EW longshore drifts, formed during the NE prevailing sea swell move sediments from the eroding rocky shores of Aghir toward the sandy spits of Kastil and Ras Rmal. Rocky coasts and cliffs are more stable and reflect a decreasing sensitivity to physical variables. The depositional features are observed in the coastal areas that are fronted by deep shoreface. Morphology of Boughrara lagoon is marked by sea cliffs and high plateaus. The average depth in the basin is about $4 \mathrm{~m}$ with a maximum of $16 \mathrm{~m}$ in the center part. The portrayal of the studied zoneshows that $155 \mathrm{~km}$ of the coast (43\%) are mapped as marshes and flats(Figure 3a), $29 \%$ of the coast as sandy shores ( $21 \%$ beaches, $8 \%$ sandy spits and Barrier Island) and $8 \%$ as rocky shores.

\section{Hinterland topography}

The hinterland topography is the most important factors that isconsidered to estimate the impact of the sea level rise on the given transects. It expresses the relative erodibility and the degree of resistance of the coast. The low lying coastal areas are exposed to the littoral inundation and flooding. However, the high plateaus are exempt to flooding risk. The northern edge of the studied area is marked by a series of hillocks. The lithological character of these plateaus consists to a conglomerate constructionwhich has been incised by drainage network. The analysis of the hinterland topography variable shows that $25 \%$ of the coast mapped as high plateaus, $28 \%$ as sebkhas, $20 \%$ as smooth shapes, $16 \%$ as lagoons and $11 \%$ as former outcrops (Figure 3b).

\section{Coastal slope}

Several transverseprofiles of the coast are analyzed in order to extract the lateral variability of the substrate slope. Coastal slopes values between $0.03^{\circ}-0.05^{\circ}$ are ranked as lower risk where hydrodynamic processes are mitigated. The beaches of the northern side of Gabes city are more energeticand shows a highly slope angle $\left(0.2^{\circ}-0.3^{\circ}\right)$. The southern band of Gabes is marked by a gently substrate slope angle $\left(0.15^{\circ} ; \mathrm{Gzam}, 2013\right)$. Around Jerba Island, bathymetry is irregular; the eastern side is marked by steep substrate where coasts are exposed to waves. The northern side is sheltered from the open sea by a wide regular platform densely occupied by sea grass. In Boughrara lagoon bathymetry is marked by the abundance of sandy shoals which are dissected by deep channels. Figure 3 (c) shows that $66 \%$ of the coast were mapped as very low angle slope $\left(0.03^{\circ}-0.059^{\circ}\right), 4 \%$ as gently inclined substrate $\left(0.06^{\circ}-0.1^{\circ}\right), 18 \%$ as moderately inclined slope $\left(0.11^{\circ}-0.3^{\circ}\right), 10 \%$ as steep angle slope $\left(0.31^{\circ}-0.5^{\circ}\right)$ and $2 \%$ as very high angle $\left(0.51^{\circ}-0.7^{\circ}\right)$.

\section{Facies}

The nearshore zone is generally formed by homogeneous well-sorted medium- to fine-grained quartzose sand $(2.2 \Phi<M z<3.3 \Phi)$. Most of these sediments in the nearshore contain shells and shell fragments. 
Mineralogical analysis shows abundance of carbonate fraction in the sediments therein amount of calcite and aragonite attains respectively $30 \%$ and 50\% (Brahim et al., 2015).The very fine sediment (3Ф< $\mathrm{Mz}<3.3 \Phi)$ is classed as lower risk. This class occurs in sheltered area with low hydrodynamic processes. Sediments are composed also by a great amount of algal and vegetal debris. The sandy shoals are marked by high energy coarser grained sediments where carbonate production is very intensive. At the eastern side of Jerba Island beaches are composed of medium to coarse sand $(1.8 \Phi<\mathrm{Mz}<2.6 \Phi)$. Figure 3 (d) indicates that $54 \%$ of the coasts were mapped as fine facies, $26 \%$ as medium facies and $20 \%$ as coarse facies.

\section{Shoreline exposure}

Shoreline exposure describes the end effects of the wave actions with littoral configuration. Shoreline exposition to the dominant wave influences its susceptibility to the submersion risk. Waves have a lesser effect on sheltered coasts. This variable is ranked as very sheltered, sheltered, semi-exposed, exposed and fully exposed. In the Gulf of Gabes, large wave amplitudes mainly correlate with high wind speed from NE direction (Amari 1984, Abdennadher and Boukthir, 2006). Sea levels appear to rise in response to wind pile-up (Sammari et al., 2006). Waveheight in the NE sector of the Gulf reaches $2.5 \mathrm{~m}$ which decrease near the shoreline $0.9 \mathrm{~m}$. Wave is strongly attenuated during its propagation by sea grass beds and shoals. The SE wave sector, with the lowest height $1.1 \mathrm{~m}$, induces a seasonal accretion along the coast. Waves originate from $E$ sector approach the coast without energy dissipation ( $h=2.2 \mathrm{~m}, \mathrm{~T}=5.5 \mathrm{~s}$ ), inducing cross-shore sediment transport. Energy dissipation from oblique waves is resulted from the longshore sediment transitand the development of sandy spits. Using a rose diagram of wave intensity, each transect was assigned a rank value according on its configuration. Figure 4 (e) shows that $70 \%$ of the coasts were mapped as sheltered to very sheltered, $11 \%$ as semi exposed, $13 \%$ as exposed and $6 \%$ as fully exposed.

\section{Shoreline changes}

Recent morphologic trend in the Gulf of Gabes is marked by shoreline progradation. Morphologic survey combined to images satellite data show that the Gulf of Gabes is marked by the genesis of a linear ridge formed since 1980's. The sheltered area is shifted to marsh domain with a branched network of tidal channels. Beaches are dissipative and tend to be the steeper with a gentle slope and wide low tide terrace which may be up to $200 \mathrm{~m}$. Rocky shores exists mainly at the western side of Jerba Island. It consists to a high former dune developed during the Holocene transgression (Frébourg et al., 2010). In term of shoreline changes, Figure 4 (f) indicates that $71 \%$ of the coast was marked by progradation, $22 \%$ of the coast was mapped as stable area, and $7 \%$ of the coast was mapped as eroding.

\section{Tide}

The tidal regime modulates the hydrosedimentary processes along the transverse profile of beaches. The lower tide range represents a higher sensitivity; with low tide range shoreline is exposed frequently to hydrodynamic processes. Thus a storm surge event has a greater probability of coinciding with a high 
tide that would cause shoreline instability and erosion. In the Mediterranean, the highest tides are observed in the Gulf of Gabes (Abdennadher and Boukthir, 2006), where tides are principally semi-diurnal in nature. The tidal range is not everywhere the same in the study area. The tidal amplitude is highest (2 $\mathrm{m}$ ) in the central part of the Gulf (Gabes) and smaller in the south: 1.3 at Jerba Island and $0.6 \mathrm{~m}$ at Boughrara lagoon (Sammari et al., 2006). Such amplitude increases sediment mobilization across the beaches. In terms of tidal regime variable, Figure $4 \mathrm{~g}$ shows that $6 \%$ of the coast were marked by a high tides of $2 \mathrm{~m}, 12 \%$ mapped with tide of between $1.9 \mathrm{~m}-1.5 \mathrm{~m}, 43 \%$ of the coast mapped with tide of between $1.4 \mathrm{~m}-1.1 \mathrm{~m}, 11 \%$ of coast mapped with tide of between $1 \mathrm{~m}-0.7 \mathrm{~m}$ and $28 \%$ of the coast mapped with tide of $0.6 \mathrm{~m}$.

\section{Sea level trend}

Based on tide gauge data the rate of global average sea level rise, during the 20th century, is in the range of $1.8 \mathrm{~mm} / \mathrm{yr}$ between 1961 and 2003 and has accelerated between 1993 and 2003 with a rate of 3.1 mm/year (IPCC, 2013; Oueslati, 2004). Otherwise, Masmoudi, 2010 affirmed that barrier coasts system of Jerba Island are governed by relative sea level change where recent sandy accumulations are contemporaneous with the actual tendency of risen sea level. Coastal marshes are abundant with $43 \%$ of the coast. It accretes vertically in response to sea-level rise (Orson et al., 1998; French, 2006). All climatic scenarios indicate a sea level rise, along the Mediterranean coast, of 3 to $14 \mathrm{~cm}$ from 1990 to 2025 (IPCC 2013). A higher value (Figure 4h); $3.1 \mathrm{~mm} / \mathrm{yr}$ ) was considered in the current study.

\section{Coastal state indicators}

Statistical quartiles were used to slice the data on the basis of the magnitude of calculated indices for all transects to highlight different relative sensitivities along the coast. The CSI scores range from 14 to 34 , with a mean of 22.7 (Figure 5; median is 22). Thus the mid-range (21-23) was considered to be moderate sensitivity zones. High sensitivity values extend from 24 to 26 . Values above 26 are assigned to the very high sensitivity category. Values below 21 are assigned to the low sensitivity. A total of $358 \mathrm{~km}$ of shoreline is ranked in four categories (Figure 5). A $12.7 \%$ of the mapped shoreline shows very high risk. An $8.6 \%$ of the coastsare classified as high sensitivity and $78.6 \%$ as moderate to low risk. The lowest sensitivity areas include the sheltered tidal flats of the studied zone. These tidal flats are backed by highplateau and governed by low hydrodynamic conditions. A significant exception to this domain (tidal flats) is recorded along the western edge of Jerba Island where marshes are scored with high sensitivity. Here morphology consists to the rocky shores densely covered by marshes. This domain is backed by lowlying inland and advanced by a relative coastal steep slope. Large section of the study area is mapped as moderate sensitivity coasts. This class was reported for wide range of coastal sections corresponding mainly to sheltered sea cliffs, rocky shores which are advanced by a large platform. High sensitivity index is attributed mainly for beaches (Gabes) fully exposed to wave action and backed by dunes and low inland. Sediments depletion is ensured by the cross-shore components and littoral drift. Coastal slope favors energy dissipation in the large surf zone. Coastal transects ranked with very high sensitivity includebarrier and sandy spits and occur along the eastern coasts of Jerba Island, which are exposed to oblique waves. The volumes of sand eroded from proximal beaches (source zone) are transferred 
laterally by littoral drift and deposited beyond morphodynamic system limits. If these volumes are not renewed sufficiently in the proximal zone, a negative sedimentary budget takes place and enhances littoral erodibility.The lateral transfer of sediments from source beaches toward end spit section presents a significant parameter to evaluate the coastal sensitivity.Such coasts have undergone recession over recent two decades and may be subject to further landward retreat during storm surges. Thus, littoral planningin these areas is not recommended because morphodynamic equilibrium is tied to littoral drift.

\section{Discussion}

\section{Sensitivity map calibration}

The resulting sensitivity map constitutes a verified support of coastal planning management. Calibration of the sensitivity map in the field includes the sites that are mapped as high to very high scores. Once occupied, these areas are immediately disturbed regardless the sensitivity index. The eastern edge of Jerba Island (mapped as very high sensitivity index) is densely eroded due to the intense human occupation of the backshore. The harbor infrastructures are threatened by silting problems.

\section{Silting up of harbor infrastructures}

The Aghir coast is located at the southeastern side of Jerba Island and is marked by the developed sandy spit of Kastil. Here the major swell directions are oblique to the shoreline. This stretch of coast is mapped as high to very high risk (CSI score is 30 ). The harbor of Aghir is fully silted up; during the spring tide period the wave action is amplified by wind force. The turbidity reaches a maximum value of 121 NTU (Atoui, 2017). The jetty constitutes an artificial barrier reducing hydrodynamic agitation and engendering preferential sediment deposits site behind the quay.As a result, there are a number of changing bars and banks behind the quay which have raised the bottom sea (Figure 2). The proposal criteria to solve cessation of harbor exploitation should take into account the shoreline orientation over the wave and wind dominant. The surf zone at Aghir coast is wide and constitutesuntil bathymetry of $10 \mathrm{~m}$ an active sediment transit zone. The optimal solution consists to the dismantling of the harbor which can be relocated 4 kilometers from the first site. The potential site susceptible to receive new location of the harbor is controlled by geomorphology. The coast with barrier island of Essaguia presents a moderate risk $(C S I=22)$ for harbor implantation. It consists to a large tidal channel sheltered from the open sea by a Holocene sandstone dune. This barrier island presents natural break water allowing the development of a large salient.

The second site calibrated in the present study is the coastline of Gabes city. This stretch of coast is mapped as moderate sensitivity and is marked by a net positive sand budget. By2006, the bathymetric contours are curved to the south jetty suggesting an active sediment deposit reaching $1235500 \mathrm{~m}^{3}$ (Studi, 2007). Harbor basin constitutes the most sheltered area near the surf zone which coincides to the harbor entrance channel.A high amount evaluated to $80 \%$ from the annual sediment transit (approximately $64800 \mathrm{~m}^{3} / \mathrm{y}$; Studi, 2007) are intercepted by the entrance channel. The wave is affected 
by diffraction before entering the sheltered harbor basin where the energy rations abruptly drop. Sand deposition causes abruptly reduction of the water depth preventing access to the harbor basin.The channel entrance of the harbor is maintained by drag-dredging operations (Figure 2).From 1964 to 2006, a total volume of sediment estimated at $2807000 \mathrm{~m}^{3}$ is dredged from the harbor basin (Sogreah, 2003). Prolongation of the fishing harbor away from the surf zone is considered as the optimal solution to avoid silting problem. The potential site susceptible to receive new location of the harbor entrance consists to the break slope angle situated at $-6.5 \mathrm{~m}$.

\section{Coastal degradation}

The northeastern edge of Jerba Island is mapped as very high sensibility zone (CSI = 30) where morphodynamic equilibrium is strongly driven by littoral drift. The littoral disturbance is exuberated once human activities (balneal units) are installed in the zone. Degradation of the dune unitthrough an excessive occupation of the backshore impliessevere erosion of touristic zone and a significant sediments transit toward the sandy spit of Ras Rmal (CSI = 34). In some localities (e.g. Sirene hotel; Figure 6) the construction is presently trapped by wave and currents. The hotel constitutes an artificial obstacle (groin) where littoral transit was interrupted. Diffraction of longshore current around the groin has led to a significant littoral degradation at the down drift side (Figure 6). From 1994 to 2018, a linear coast of $40 \mathrm{~m}$ length was eroded at high rate retreat $(2.1 \mathrm{~m} / \mathrm{yr}$; Oueslati, 2004). Disturbance of the coast is detected either along the sandy spit of Ras Rmal. Dune unit is marked by asymmetric profile; foredune is characterized by an abrupt slope and avalanche. Morphodynamic readjustment along the shoreline is explained by notable recession of the coast. Actually, the sandy spit of Ras Rmal become thinner and longer.

\section{Planning and adequate solutions}

Littoral partition displays the cell-based template to store and portray data for each grid cells of $1.5 \mathrm{~km}$ (Thieler and Hammar-Klose, 1999). This raster approach may confuse the attribution of morphology, hinterland topography and other structural variables when coastal area shows abrupt variation in the feature along $1.5 \mathrm{~km}$ of linear coast. The morphologic classification approach that has been retained in this study might be more appropriately used for applying the CSI tool. Based on morphologic classification of the coast, each section presents a morphodynamic cell according to the physical and structural variables. Accordingly, the CSI must inform on the adequate activity which integrates coastal zone without compromising natural equilibrium. Harbors integration in the coastal areas is based on the understanding of natural dynamics and processes. The silting problem is revealed along different coastal sensitivity indexranging from very high to moderate sensitivity. These morphologic transects are marked by an active sediments transit. The lateral transfer of sediments constitutesa serious problem of disturbance once harbors or jetties are managed. Thus relocation of harbor infrastructures inland and trough tidal channel constitutes adequate solution to guarantee sustainable management of the coast. Generally, tidal channels are maintained and dredged regularly by violent tidal currents. The semi-diurnal tidal regime that characterizes the Gulf of Gabes allows the integration for harbor infrastructures. Several 
potential sites susceptible to receive harbors are identified in the coastal zone such as the tidal channel of Mezessar and Saguia (Figure 2). The best example is illustrated by the tidal channel of El Grine which is presently occupied by fishing harbor (Figure 2). For tourism development, hotels building must be outside the dune unit. Tourism development must take into account numerous parameters enhancing sensitivity of coastal areas. Shoreline changes invoke littoral progradation which consolidate littoral stability. This parameter must incorporate in long-term planning scheme of the coast. The challenge for coastal governance is to create a dynamic collaboration carrying together scientists, entrepreneurs, naturalists and policy-makers. Collective responsibility and coordination between different contributors is a certain approach for dynamic coastal governance (De Ruig, 1998; De Ruyck et al., 2001). Burbridge and Humphrey (1999) consider that resolving littoral problem is put on linkages between social, bio-chemical, geophysical and economic factors.

\section{Conclusions}

Fifty six morphologic segments were deduced from the detailed description of the studied coast (Gulf of Gabes). Each analyzed segment constitutes a coherent morphodynamic cell where the controlling parameters are digitized and included in a flexible data base. The resultant data's and their respective parameters can be adjusted and calibrated to local situation. The digitized segments exhibit index value (CSI) on depend to the ranked variables. The lowest sensitivity zones $(\mathrm{CSI}=14)$ are mapped at the central part of the studied zones and consist to a sheltered flats which are backed by a high stable cliff. Assessment of coastal sensitivity may introduce strategic planning for use to prioritize appropriate maritime planning in the Gulf of Gabes. With lower risk, the harbor sites are in line with sheltered rocky shores andcoasts with inland tidal channel. Hotels and leisure cornice integrates easily prograded sandy coasts having a moderate sensitivity. The shoreline exposition to littoral drift is the most critical indicators that exhibit the highest coastal sensitivity.Safety against littoral degradation consists on the adequate choice of feasible solutions for use to resolve littoral disturbance in the Gulf of Gabes.

\section{Declarations}

Acknowledgements The research work is carried in the Higher Institute of Water Sciences and Technics (University of Gabes).

Author Contributions Maher Gzam (Conceptualization, developing the research idea; writing the firstdraft; analyze the output of the vulnerability map); Basma Mansouri(preparation and analyze the parameters and digitize the ranked variables and image plots), Dorra Gargouri (Review the original draft), Adel Kharroubi (visualization and supervision). All authorshave read and agreed to the published version of the manuscript.

Data AvailabilityThe datasets generated during and/or analysed during the current study are available from the corresponding author on reasonablerequest. 
Declarations Conflict of Interest The authors declare no conflict of interest.

\section{References}

1. Abdennadher, J.,Boukthir, M. 2006.Numerical simulation of the barotropic tides in the Tunisian shelf and the strait of Sicily. J. Mar. Syst. 63:162-182.

2. Abuodha, P. A. O., Woodroffe, C. D. 2010.Assessing vulnerability to sea-level rise using a coastal sensitivity index: a case study from southeast Australia.J. Coast. Conserv. 14 : 189-205.

3. Atoui, A. 2017. Modélisation de la dynamique sédimentaire : application du Golfe de Gabès. Thèse de doctorat,Univ. Tunis, Ec. Nat. Ing. Tunis130 p.

4. Bardi, I. 2010.Morphodynamique de la cote sableuse microtidale a barres le long de lafrange littorale Gabes-Oued Ferd (Golfe de Gabes-Tunisie). Thèse de doctorat, Univ.Tunis el Manar, Fac. Sci. Tunis. 202 p.

5. Bejaoui, B., Rais, S.,Koutitonsky, V. 2004.Modélisation de la dispersion du Phosphogypse dans le golfe de Gabes. Bull. Inst. Natn. Sci. Tech. 31 : 103-109.

6. Ben Amor, R.,Brahim, M., Gueddari, M. 2003.Essai d'interprétation de la dynamique sédimentaire par l'analyse granulométrique et minéralogique au large du golfe de Gabes. Bull.Inst.Sci.Tech. 30: 143151.

7. Bouchahma, M., Yan, W. 2014.Monitoring shoreline change on Djerba Island using GIS and multitemporal satellite data.Arab J. Geosci.7:3705-3713

8. Brahim,M.,Atoui, A.,Sammari, C.,Aleya, L.2014.Surface sediment dynamics along the eastern coast of Djerba Island (Gabes Gulf, Tunisia). J.A.Ear.Sci. 92: 45-54

9. Brahim,M., Atoui, A.,Sammari, C., Aleya, L.2015.Surface sediment dynamics along the Tunisian coast at Skhira (Gulf of Gabes, south-eastern Tunisia). J. A. Ear. Sci. 112: 73-82

10. Burbridge, P., Humphrey, S. 1999. On the integration of science and management in coastal management research. J. Coast. Conserv.5: 103-104

11. De Ruig, J.H.M. 1998. Coastline management in The Netherlands: human use versus natural dynamics. J. Coast. Conserv. 4: 127-134

12. De Ruyck, A.M.C., Carole, A., Roger, L. 2001.Management of the Belgian coast: Opinions and solutions. J. Coast. Conserv. 7: 129-144

13. Diez, P.G., Perillo G. M.E., Piccolo, C. M. 2007. Vulnerability to sea-level rise on the coast of the Buenos Aires Province.J. Coast. Res. 23: 119-126.

14. Frébourg, G., Hasler, C.A., Davaud, E., 2010. Catastrophic event recorded among Holocene eolianites (Sidi Salem Formation, SE Tunisia). Sedimentary Geology, 224: 38-48

15. Gargouri, D.,'Gzam, M.; Kharroubi, A., Jedoui, Y. 2018. Use of sediment quality indicators for heavy metals contaminationand ecological risk assessment in urbanized coastal zones. Environ. Earth Sci. doi.org/10.1007/s12665-018-7567-3 
16. Gibb, J.G. 1981. Coastal Hazard mapping as a Planning Technique for Waiapu County, East Coast, North Island, New Zealand. Water and soil technical publication 63p.

17. Gibb, J.G., Sheffield, A., Foster, G. 1992. A standardisedcoastalsensitivityindexbased on an initial framework for physical coastal hazards information. Department of conservation science and research series, 101p.

18. Gornitz, V.M. 1990.Vulnerability of the east coast, USA to future sea level rise.J. Coas. Res. 9: 201237.

19. Gzam, M. 2013.Evolution récente du littoral du golfe de Gabès à l'épreuve des changements globaux : approche pluridisciplinaire et démarche prospective. Thèse de doctorat, Univ. Sfax, Fac. Sci. Sfax. $242 \mathrm{p}$.

20. Gzam, M.,Serbaji, M. M.,Ouaja, M.,Jedoui, Y. 2013a.Coastal progradation in response to the recent sea level rise: a case study of El Grine coast, Gulf of Gabes (Southeastern Tunisia). Arab. J. Geo. sci. $6: 5007-5016$

21. Gzam,M., Zagrarni,M. F., Jedoui, Y. 2013b.Interaction morphodynamique d'une plage sableuse dans une conjoncture d'el'evation du niveau marin; exemple du littoral de Trab el Makhadha dans le golfe de Gabes-Tunisie.La Houille Blanche, 3 : 21-29.

22. Gzam, M.,Elmejdoub, N.,Boussetta, S.,Jedoui, Y. 2014.Genesis and evolution of a beach-ridge plain reflecting relative sea-level rise: A case study from trab el makhadhaGulf of Gabes, southeastern Tunisia. J. Sedim. Res. 84: 183-191.

23. IPCC, 2013.Summary for Policymakers. In: Stocker, T.F., Qin, D., Plattner, G-K., Tignor, M., Allen, S. K., (Eds.), Climate Change 2013: The Physical Science Basis. Contribution of Working Group I to the Fifth Assessment Report of the Intergovernmental Panel on Climate Change. Cambridge University Press Cambridge, United Kingdom and New York, NY, USA.

24. Kharroubi, A.,Gzam, M.,Jedoui, Y. 2012. Anthropogenic and natural effects on the water and sediments qualities of coastal lagoons: case of the Boughrara Lagoon (Southeast Tunisia). Environ Earth Sci. 67: 1061-1067.

25. Koroglua, A., Ranasinghea, R., Jiméneze, J. A., Dastgheiba, A. 2019. Comparison of coastal vulnerability index applications for Barcelona Province.Oce. Coast. Manag. 178 : 104799

26. Masmoudi,S. 2010.Evolution morphodynamique, sédimentologique et variation du niveau relatif de la mer de l'Holocène à l'actuel : cas du système des côtes barrières de Jerba-Zarzis (Sud-Est Tunisien). Thèse de doctorat, Univ. Sfax, Fac.Sci. Sfax 249 p.

27. Maghrebi, S. 1995. Dynamique sédimentaire dans le Golfe de Gabes (Tunisie). Impact des aménagements cotières. Thèse de doctorat, Univ. Paris Sud, 174 p.

28. Oueslati, A. 2004. Littoral et aménagement en Tunisie. Ed ORBIS. 534 p

29. Palmer, B. J., Van der Elst, R., Mackay, F., Mather, A A., Smith, A. M., Bundy, S. C., Thackeray, Z.,Leuci, R.,Parak, O. 2011.Preliminary coastal vulnerability assessment for KwaZulu-Natal, South Africa.J. Coas. Res. 64: 1390-1395 
30. Paskoff, R. 1994. Les littoraux. Impact des aménagements sur leur évolution. Paris Masson, 2 ème édition, $256 \mathrm{p}$.

31. Ramieri, E., Hartley, A.,Barbanti, A., Santos, F. D.,Gomes,A.,Hilden, M.,Laihonen, P.,Marinova,N.,Santini, M. 2011. Methods for assessingcoastalvulnerability to climate change, ETC CCA Technical Paper 93 p.

32. Saïdi, H.B.,Souissi, R.,Zargouni, F. 2011. Detached breakwaters' effects on a microtidal Mediterranean Coast, case of the Hammam-Lif littoral (North-East of Tunisia).J. Coast.Conserv. 15: 523-529

33. Shaw, J., Taylor, R. B., Forbes, D. L., Ruz, M-H., Solomon, S. 1998.Sensitivity of the coasts of Canada to sea-level rise.Bull. Geol. Surv. Canada, $505: 1-79$.

34. Sogreah. 2003. Protection des ressources marines et côtières du golfe de Gabès, phase préparatoire du projet GEF/WB TF 022968. Rapport inédit, $105 \mathrm{p}$.

35. Studi -Société Tunisienne d'Ingénierie 2007. Etude de protection du port de pêche de Gabès "étude de la solution retenue". Rapport inédit, $70 \mathrm{p}$.

36. Thieler E.R., Hammar-Klose, E.S. 1999. National assessment of coastal vulnerability to sea level rise: preliminary results for the U.S. Atlanta coast USGS, Open File report 99-593.

\section{Figures}

\section{Figure 1}

Location of study area

\section{Figure 2}

Current situation of harbor infrastructures in the Gulf of Gabes.A: channel entrance of Gabes harbor is maintained by drag-dredging operations, $B$ : total cessation of Aghir harbor exploitation due to severe sandy accumulations.

\section{Figure 3}

The relative ranking of structural variables: (a) geomorphology, (b) hinterland topography, (c) coastal slope and (d) sediment facie for the Gulf of Gabes.

\section{Figure 4}


The relative ranking of process variables: (e) shoreline exposure $(f)$ shoreline changes $(g)$ tide $(h)$ sealevel trend for the Gulf of Gabes.

\section{Figure 5}

Coastal sensitivity map of the Gulf of Gabes.

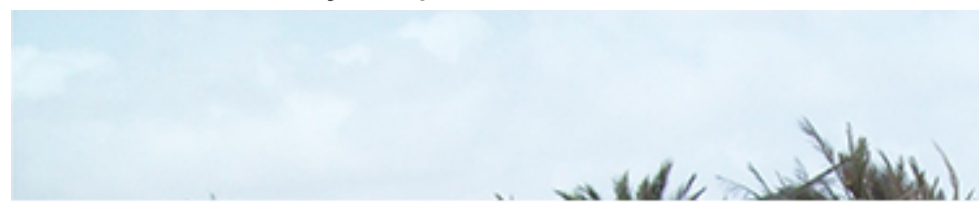

Figure 6

Severe littoral erosion observed at the down-drift side after longshore diffraction around hotel construction. 